\title{
Antioxidant Activity Test of Ethanol and Water Extracts of Celery (Apium graveolens L.)
}

\author{
*Nurmiati, Siti Nuryanti \& Tahril \\ Pendidikan Kimia/FKIP - Universitas Tadulako, Palu - Indonesia 94119 \\ Received 12 March 2020, Revised 14 April 2020, Accepted 14 May 2020 \\ doi: 10.22487/j24775185.2020.v9.i2.pp93-101
}

\begin{abstract}
This study aimed to determine the antioxidant activity of ethanol and water extracts of celery (Apium graveolens L.). Antioxidant activity test in this study used DPPH (2,2-diphenyl-1-pikrilhidrazil) as a source of free radicals and vitamin $C$ as a positive control. The antioxidant activity of celery extracts were analyzed using UV-VIS spectrophotometer. Celery powder was extracted by firstly the maceration method using different solvents (ethanol and water) and secondly with the decoction method using water solvents. Celery extract was tested for antioxidant activity with various concentrations of 20, 40, 60, and $80 \mathrm{ppm}$. The results obtained that water extract (maceration) had a very strong antioxidant power with $23.713 \mathrm{ppm}$ of $I C_{50}$ values, for ethanol extract (maceration) had a strong antioxidant power with $59.492 \mathrm{ppm}$ of IC $\mathrm{C}_{50}$ value, water extract (dekok) had also a very strong antioxidant with $77.446 \mathrm{ppm}$ of $I C_{50}$ value, and vitamin $C$ had a very strong antioxidant power with $15.631 \mathrm{ppm}$ of an $I_{50}$ value. Based on the $I C_{50}$ value obtained, the water extract by maceration method was very good to be used as a source of natural antioxidants, because it had a very strong antioxidant activity value which was equivalent to vitamin $C$.
\end{abstract}

Keywords: Antioxidants, celery, extract, ethanol, water, DPPH, UV-VIS spectrophotometer, $\mathrm{IC}_{50}$

\section{Pendahuluan}

Seledri biasa digunakan sebagai bahan bumbu masak atau pelengkap hidangan (Hariani, 2006). Menurut penelitian Sukahor \& Arisandi (2016), seledri mengandung sejumlah zat aktif, antara lain apigenin dan phtalide yang dapat bermanfaat sebagai agen kemopreventif untuk pasien kanker. Agen kemopreventif pada umumnya memiliki aktivitas penghambatan perkembangan kanker serta dapat meningkatkan kemungkinan kesembuhan dan menurunkan rasa sakit yang dialami oleh penderita kanker. Penyebab kanker adalah reaksi kimia yang dilakukan oleh radikal bebas.

Radikal bebas merupakan molekul yang tidak stabil dan sangat reaktif karena memiliki elektron tidak berpasangan pada orbit terluarnya. Untuk mencapai kestabilan radikal bebas akan bereaksi dengan molekul disekitarnya untuk memperoleh pasangan elektron, reaksi ini akan berlangsung terus menerus dalam tubuh dan sangat mudah menyerang sel-sel sehat di dalam tubuh. Apabila radikal tidak dihentikan akan menimbulkan berbagai penyakit seperti penuaan dini, kanker, lever serta penyakit degeneratif lainnya. Oleh karena itu tubuh memerlukan pertahanan untuk menetralkan radikal bebas tersebut yaitu dengan senyawa antioksidan (Hernani \& Raharjo, 2005).

Antioksidan dapat menetralkan radikal bebas dengan cara mendonorkan satu atom protonnya sehingga membuat radikal bebas stabil dan tidak reaktif (Singh, 2004). Tubuh manusia menghasilkan senyawa antioksidan, tetapi jumlahnya sering kali tidak cukup untuk menetralkan radikal bebas yang masuk ke dalam tubuh (Hernani \& Rahardjo, 2005). Jumlah radikal bebas dapat mengalami peningkatan yang diakibatkan oleh faktor stres, radiasi, asap rokok, dan polusi lingkungan yang menyebabkan sistem pertahanan tubuh yang ada tidak memadai, sehingga tubuh memerlukan tambahan antioksidan dari luar (Wahdaningsih, dkk., 2011). Berdasarkan sumbernya antioksidan dibagi menjadi 2 kelompok yaitu antioksidan sintetik dan antioksidan alami. Antioksidan sintetik dibuat dari bahan kimia sedangkan antioksidan alami berasal dari tumbuhan yaitu senyawa fenolik yang dapat berupa turunan asam sinamat, kumarin, tokoferol, asam organik polifungsional, dan golongan flavonoid (Isninandar, dkk., 2011).

Flavonoid dimiliki oleh banyak tanaman. Salah satu tanaman yang mengandung flavonoid adalah seledri. Kandungan yang terdapat dalam seledri yaitu minyak atsiri, apiin, apigenin,

${ }^{*}$ Correspondence:

Nurmiati

e-mail: nurmiatijabir@gmail.com

(c) 2020 the Author(s) retain the copyright of this article. This article is published under the terms of the Creative Commons Attribution License 4.0, which permits unrestricted non-commercial use, distribution, and reproduction in any medium, provided the original work is properly cited. 
saponin, flavonoid, polifenil, kalori, protein, lemak, hidrat arang, kalsium, fosfor, besi, vitamin A, vitamin B, dan vitamin C (Bardan, 2007). Menurut penelitian Kusnadi \& Devi (2017) bahwa terdapat senyawa flavonoid pada ekstrak daun seledri. Flavonoid merupakan senyawa yang bersifat polar, pelarut polar yang biasa digunakan untuk ekstraksi flavonoid adalah metanol, aseton, isopropanol, etanol, dan air. Tulisan ini dimaksudkan untuk mendeskripsikan daya aktivitas antioksidan ekstrak etanol dan ekstrak air dari seledri (Apium graveolens L.).

\section{Metode}

Alat dan bahan yang digunakan dalam penelitian ini yaitu loyang, pisau, talenan, blender, neraca analitik, ayakan No.80 mesh, shaker, erlenmeyer, gelas kimia, spatula, batang pengaduk, botol semprot, pipet tetes, corong, labu ukur, aqua bath, stopwatch, kuvet, spektrofotometer UV-Vis, aluminium foil. seledri, etanol 96\% (Merck), aquadest, DPPH (2,2-difenil-1-pikrilhidrazil) (Merck), dan Vitamin C (Merck).

\section{Prosedur Penelitian}

\section{Preparasi Sampel}

Preparasi sampel pada penelitian ini dilakukan menggunakan modifikasi dari Bahriul dkk. (2014). Perlakuan pertama yaitu menyiapkan sampel seledri, yang diperoleh dari pasar sentral Inpres Manonda Palu Sulawesi Tengah. Tanaman seledri berasal dari Desa Nupabomba, Kabupaten Donggala, Sulawesi Tengah. Seledri dicuci dengan air mengalir hingga bersih kemudian dipotong kecil-kecil dan dikeringkan dengan cara diangin-anginkan selama 5 hari pada suhu ruang. Perlakuan selanjunya adalah menghaluskan seledri yang sudah dikeringkan dengan blender, kemudian diayak menggunakan ayakan 80 mesh. Setelah itu sampel halus siap digunakan untuk analisis.

\section{Ekstraksi Sampel Seledri}

Serbuk kering seledri diekstraksi dengan menggunakan dua metode yang berbeda yaitu sebagai berikut:

\section{Ekstraksi Seledri Menggunakan Pelarut Etanol dengan Metode Maserasi}

Ekstraksi seledri dilakukan menggunakan modifikasi prosedur dari Rizkayanti, dkk. (2017). Ekstrak seledri dibuat dengan mengekstraksi 25 gram serbuk seledri secara maserasi dengan pelarut etanol hingga terekstraksi sempurna. Simplisia direndam dalam $250 \mathrm{~mL}$ pelarut etanol $96 \%$ selama 2 × 24 jam dengan pengadukan konstan setiap harinya selama 3 jam dengan menggunakan shaker. Setelah itu maserat yang diperoleh disaring kemudian filtrat yang diperoleh dicukupkan volumenya dengan etanol $96 \%$ hingga $250 \mathrm{~mL}$.

\section{Ekstraksi Seledri Menggunakan Pelarut Air dengan Metode Maserasi dan Metode Dekok}

Metode maserasi untuk pelarut air perlakuannya sama dengan metode maserasi pelarut etanol hanya saja menggunakan aquadest sebagai pelarutnya sedangkan untuk metode dekok dilakukan menggunakan modifikasi prosedur dari Rizkayanti, dkk. (2017). 25 gram serbuk seledri dimasukkan ke dalam gelas kimia dan ditambahkan aquadest hingga $250 \mathrm{~mL}$, selanjutnya dipanaskan dalam alat aqua bath selama 30 menit (waktu 30 menit dihitung setelah suhu dalam gelas kimia telah mencapai $90^{\circ} \mathrm{C}$ ). Setelah itu hasil dekok yang diperoleh disaring kemudian filtrat yang diperoleh dicukupkan volumenya dengan aquadest hingga $250 \mathrm{~mL}$.

\section{Uji Aktivitas Antioksidan}

\section{Pembuatan Larutan DPPH 200 ppm}

20 mg DPPH dilarutkan dengan etanol 96\% dalam labu ukur $100 \mathrm{~mL}$, kemudian dicukupkan volumenya dengan etanol $96 \%$ sampai garis tanda.

\section{Pembuatan Larutan Blanko 100 ppm}

Larutan DPPH 200 ppm dipipet $12.5 \mathrm{~mL}$, kemudian dimasukkan ke dalam labu ukur $25 \mathrm{~mL}$ dan dicukupkan volumenya dengan etanol 96\% sampai garis tanda.

\section{Pembuatan Larutan Uji Ekstra Etanol dan Ekstrak Air Seledri}

Ekstrak etanol dan ekstrak air masing-masing dipipet $1 \mathrm{~mL}$, kemudian dimasukkan ke dalam labu ukur $100 \mathrm{~mL}$. Labu pertama kemudian dicukupkan volumenya dengan etanol 96\% sampai garis tanda, labu kedua dan labu ketiga dicukupkan volumenya dengan aquadest sampai garis tanda sehingga diperoleh masing-masing konsentrasi 1000 ppm. Kemudian dari masingmasing larutan tersebut dibuat seri konsentrasi, dengan cara larutan induk dipipet masing-masing 1, 2, 3, dan $4 \mathrm{~mL}$, kemudian masing-masing larutan dimasukkan ke dalam labu ukur $50 \mathrm{~mL}$ yang berbeda-beda dan dicukupkan volumenya dengan etanol 96\% untuk ekstrak etanol seledri dan aquadest untuk ekstrak air seledri sampai garis tanda sehingga diperoleh seri konsentrasi 20, 40, 60, dan 80 ppm.

\section{Pembuatan Larutan Pembanding Vitamin C}

$25 \mathrm{mg}$ vitamin $\mathrm{C}$ dilarutkan dengan etanol $96 \%$ dalam labu ukur $25 \mathrm{~mL}$, kemudian dicukupkan volumenya dengan etanol 96\% sampai garis tanda sehingga diperoleh vitamin $\mathrm{C}$ 
1000 ppm. Kemudian larutan tersebut dibuat seri konsentrasi, dengan cara larutan induk dipipet masing-masing $0.5,1,1.5$, dan $2 \mathrm{~mL}$, kemudian masing-masing larutan dimasukkan ke dalam labu ukur $25 \mathrm{~mL}$ yang berbeda-beda dan dicukupkan volumenya dengan etanol 96\% sampai garis tanda sehingga diperoleh seri konsentrasi 20, 40, 60, dan $80 \mathrm{ppm}$.

\section{Pengukuran Serapan Blanko}

Larutan blanko dimasukkan ke dalam kuvet, kemudian diukur absorbansinya dengan spektrofotometer UV-VIS pada panjang gelombang $517 \mathrm{~nm}$ dan pengukuran dilakukan $3 \mathrm{x}$ pengulangan, semua pengerjaan dilakukan dalam ruangan yang terhindar dari cahaya matahari (Sulaeha, dkk., 2017).

Pengukuran Serapan Larutan Uji Ekstrak Etanol dan Ekstrak Air Seledri, dan Larutan Pembanding Vitamin $C$

Pengukuran serapan dilakukan menggunakan modifikasi prosedur dari Sulaeha, dkk. (2017). Masing-masing $5 \mathrm{~mL}$ larutan uji ekstrak etanol seledri, ekstrak air seledri, dan vitamin $\mathrm{C}$ dengan berbagai konsentrasi $(20,40$, 60, dan $80 \mathrm{ppm}$ ) ditambahkan $5 \mathrm{~mL}$ larutan DPPH, campuran dihomogenkan dan dibiarkan selama 30 menit. Selanjutnya diukur absorbansinya dengan spektrofotometer UV-VIS pada panjang gelombang $517 \mathrm{~nm}$ dan pengukuran dilakukan $3 \mathrm{x}$ pengulangan, semua pengerjaan dilakukan dalam ruangan yang terhindar dari cahaya matahari.

\section{Analisa Data}

Aktivitas antioksidan penghambatan radikal bebas DPPH ekstrak seledri (Apium graveolens L.) dan vitamin $\mathrm{C}$ dianalisis, masing-masing dihitung harga $\mathrm{IC}_{50}$ melalui analisis probit. Selanjutnya, hasil analisis probit dibandingkan dengan tingkat kekuatan antioksidan. Berikut ini tahapan dalam menghitung nilai $\mathrm{IC}_{50}$ ekstrak seledri dan vitamin C.

\section{Pengukuran persen penghambat seledri dan pembanding vitamin $C$}

Pengukuran absorbansi serapan diukur pada panjang gelombang $517 \mathrm{~nm}$. Kemudian absorbansi digunakan untuk menghitung persen penghambat dengan rumus (Sharon, dkk., 2013):

$\%$ penghambat $=\frac{(\text { abs blanko-abs sampel })}{\text { abs blanko }} \times 100 \%$

\section{Menghitung Nilai Probit}

Menghitung nilai probit digunakan persen penghambatan, kemudian dapat diperoleh nilai probit dengan rumus (Zuhra, dkk., 2008):

Probit $=($ Harga probit tertinggi - Harga probit terendah) (Daya antioksidan (\%)Probit terendah) + Harga probit terendah.

\section{Menghitung Nilai $I_{50}$}

Nilai $\mathrm{IC}_{50}$ ditentukan dengan menghitung persen penghambatan yang kemudian digunakan untuk menghitung nilai probit pada tahap sebelumnya. Nilai probit yang didapatkan kemudian diplotkan dengan nilai log konsentrasi sehingga mendapatkan persamaan regresi $\mathrm{y}=\mathrm{ax}$ + b. Persamaan regresi tersebut kemudian digunakan untuk mencari nilai $\mathrm{IC}_{50}$ (x pada persamaan regresi) dengan mengganti nilai $y$ sebesar 5 dari harga probit 50\%. Kemudian nilai $\mathrm{x}$ diplotkan menjadi antilog $\mathrm{x}$ sehingga diperoleh nilai $\mathrm{IC}_{50}$.

\section{Hasil dan Pembahasan}

\section{Ekstraksi Seledri dengan Pelarut Etanol dan Air}

Ekstraksi merupakan suatu proses selektif yang dilakukan untuk mengambil zat-zat yang terkandung dalam suatu campuran dengan menggunakan pelarut yang sesuai. Metode pemisahan ini bekerja berdasarkan prinsip kelarutan like dissolve like, yaitu pelarut polar akan melarutkan zat polar, dan sebaliknya (Khopkar, 2014).

Proses ekstraksi seledri dilakukan dengan dua cara yaitu cara dingin metode maserasi dan cara panas metode dekok. Metode maserasi didasarkan pada perendaman sampel di dalam pelarut sehingga pelarut akan menembus dinding sel dan masuk ke dalam rongga sel yang mengandung senyawa aktif, pada metode maserasi digunakan dua pelarut yaitu etanol $96 \%$ dan air sedangkan metode dekok merupakan metode ekstraksi dengan proses pemanasan, pelarut yang digunakan pada metode ini adalah air. Pelarut air digunakan untuk menggambarkan cara penggunaan seledri di dalam masyarakat sebagai sayuran dan obat.

Data warna ekstrak seledri menggunakan pelarut etanol dan air dengan metode maserasi dan pelarut air dengan metode dekok disajikan pada Tabel 1. 
Tabel 1. Warna ekstrak seledri

\begin{tabular}{cccc}
\hline \multirow{2}{*}{ Sampel } & \multicolumn{3}{c}{ Warna Ekstrak } \\
\cline { 2 - 4 } & \multicolumn{2}{c}{ Metode maserasi } & Metode dekok \\
\cline { 2 - 4 } & Etanol & Air & Air \\
\hline Seledri & Hijau pekat & Merah kecoklatan & Merah kecoklatan \\
\hline
\end{tabular}

Hasil yang diperoleh dari proses ekstraksi memiliki perbedaan warna, perbedaan warna kemungkinan disebabkan adanya perbedaan jumlah senyawa aktif yang terdapat dalam ekstrak dan tingkat kepolaran dari kedua pelarut, sehingga warna ekstrak yang diperoleh berbeda.

Etanol memiliki dua gugus yang berbeda kepolarannya yaitu gugus hidroksi yang bersifat polar dan gugus alkil yang bersifat nonpolar sehingga senyawa-senyawa dengan polaritas yang berbeda dapat terekstrak dalam pelarut etanol sedangkan air mampu mengekstrak senyawa yang bersifat polar karena memiliki gugus hidroksi (Lumempow, dkk., 2012).

Warna hijau pekat pada ekstrak terbentuk karena pelarut etanol yang digunakan tidak hanya mengekstraksi senyawa flavonoid, melainkan juga mengekstraksi klorofil yang ada dalam tumbuhan (Koirewoa, dkk., 2012). Warna hijau pada ekstrak juga dapat disebabkan oleh pigmen kuinon, warna pigmen kuinon mulai dari kuning muda sampai hitam muda. Pigmen ini sering terdapat dalam kulit, akar atau dalam jaringan lain misalnya daun (Harborn, 1987). Sedangkan warna merah kecoklatan pada ekstrak diduga merupakan pigmen antosianin, antosianin merupakan pigmen tanaman yang larut dalam pelarut polar yang memberikan warna merah, ungu hingga biru pada tanaman tingkat tinggi, warna coklat pada ekstrak dapat pula disebabkan adanya tanin (Harborn, 1987).

\section{Uji Aktivitas Antioksidan}

Uji aktivitas antioksidan pada seledri menggunakan DPPH (2,2-difenil-1-pikrilhidrazil) sebagai penyedia radikal bebas. Metode uji antioksidan menggunakan DPPH dipilih karena merupakan metode uji yang sederhana, mudah, cepat, sensitif, serta hanya memerlukan sedikit sampel untuk pengujian aktivitas antioksidan dari senyawa bahan alam (Molyneux, 2004).

Prinsip pengukuran aktivitas antioksidan secara kuantitatif menggunakan metode DPPH adalah adanya perubahan intensitas warna ungu DPPH yang sebanding dengan konsentrasi larutan DPPH tersebut. Radikal bebas DPPH yang memiliki elektron tidak berpasangan akan memberikan warna ungu, warna akan berubah menjadi kuning saat elektronnya berpasangan (Molyneux, 2004).

Perubahan intensitas warna ungu ini terjadi karena adanya peredaman radikal bebas yang dihasilkan oleh bereaksinya molekul DPPH dengan atom hidrogen yang dilepaskan oleh molekul senyawa sampel sehingga terbentuk senyawa 2,2-difenil-1-pikrilhidrazin dan menyebabkan terjadinya peluruhan warna DPPH dari ungu ke kuning. Perubahan warna ini akan memberikan perubahan absorbansi pada panjang gelombang maksimum DPPH saat diukur menggunakan spektrofotometer UV-Vis sehingga akan diketahui nilai aktivitas peredaman radikal bebas yang dinyatakan dengan nilai $\mathrm{IC}_{50}$ (Molyneux, 2004). Struktur kimia pereaksi DPPH bereaksi dengan senyawa antioksidan pada Gambar 1.

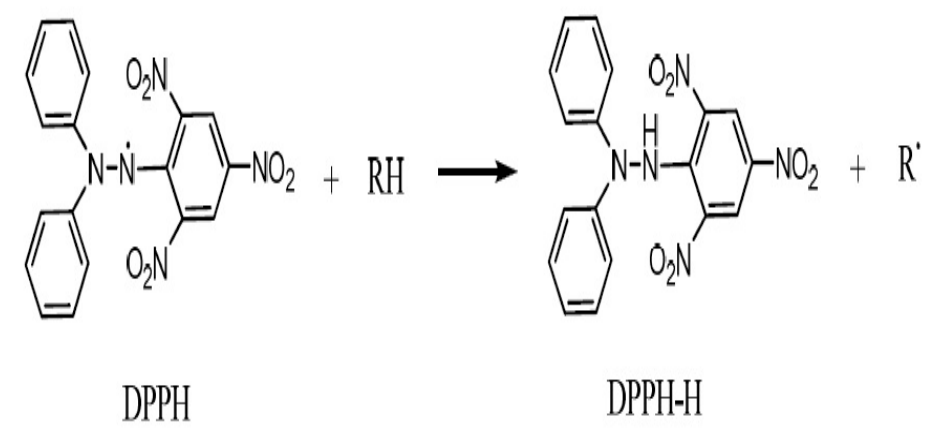

Gambar 1. Reaksi 2,2-difenil-1-pikrilhidrazil (DPPH) dengan antioksidan menghasilkan 2,2-difenil1-pikrilhidrazin (DPPH-H) (Molyneux, 2004).

Hasil pengukuran absorbansi ekstrak seledri dan vitamin C, pada berbagai konsentrasi disajikan pada Gambar 2. Data tersebut menunjukkan bahwa nilai absorbansi DPPH semakin berkurang 
seiring dengan bertambahnya konsentrasi ekstrak seledri. Hal ini dapat terjadi karena adanya reduksi radikal DPPH oleh antioksidan, dimana semakin tinggi konsentrasi ekstrak seledri maka partikel-partikel senyawa antioksidan yang terkandung akan semakin banyak sehingga semakin besar pula aktivitas antioksidannya dan menyebabkan absorbansi DPPH semakin berkurang (Talapessy, dkk., 2013). Hal yang sama juga terlihat pada pembanding vitamin $\mathrm{C}$, dimana seiring dengan bertambahnya konsentrasi vitamin $\mathrm{C}$, maka absorbansi DPPH semakin berkurang.
Semakin banyaknya senyawa antioksidan akan menyebabkan semakin besar pula peredaman warna ungu dari DPPH. Peredaman tersebut dihasilkan oleh bereaksinya molekul DPPH dengan atom hidrogen yang dilepaskan suatu molekul komponen sampel, sehingga terbentuk senyawa DPPH-H dan menyebabkan terjadinya peluruhan warna dari ungu ke kuning. Perubahan warna inilah yang mengakibatkan semakin menurunnya absorbansi pada setiap konsentrasi.

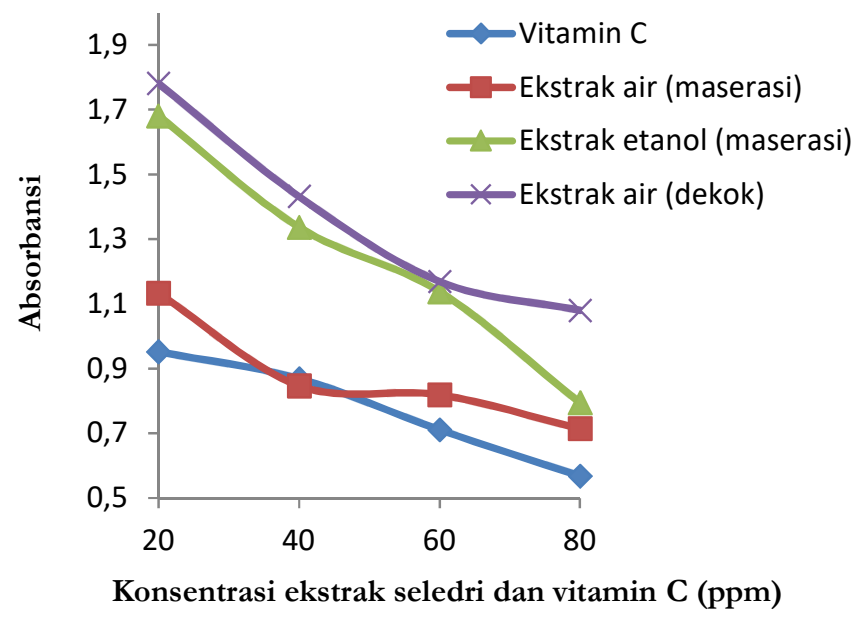

Gambar 2. Hubungan nilai absorbansi DPPH dengan konsentrasi ekstrak seledri dan vitamin $\mathrm{C}$.

Nilai absorbansi yang diperoleh kemudian digunakan untuk menghitung persen penghambat radikal bebas dari ekstrak seledri dan vitamin $\mathrm{C}$ pada berbagai konsentrasi disajikan pada Gambar 3. Persen penghambat merupakan salah satu parameter yang menunjukkan suatu antioksidan dalam menghambat radikal bebas. Semakin tinggi persen penghambat menunjukkan banyaknya atom hidrogen yang diberikan oleh senyawa aktif kepada radikal bebas DPPH sehingga DPPH tereduksi menjadi DPPH-H (Zuhrotun, dkk., 2015).

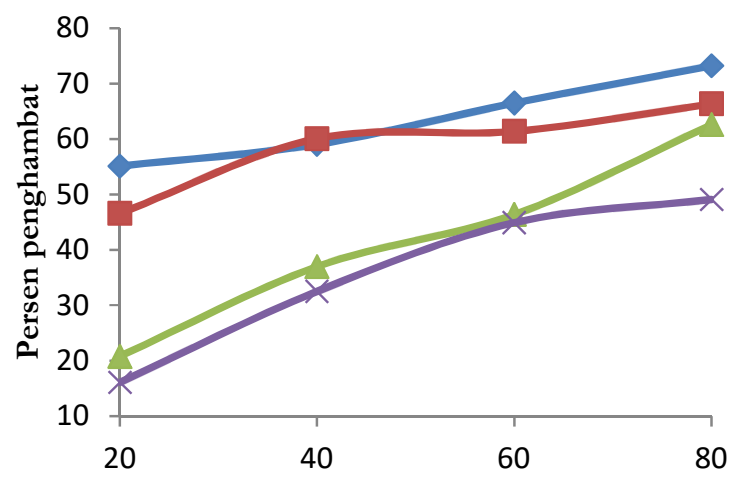

Konsentrasi ekstrak seledri dan vitamin C

(ppm)

Gambar 3. Hubungan konsentrasi dengan persen penghambat ekstrak seledri dan vitamin C.

Gambar 3 menjelaskan bahwa semakin tinggi konsentrasi ekstrak seledri maka semakin tinggi persen penghambat radikal DPPH. Persen penghambat radikal tertinggi yaitu pada 
konsentrasi $80 \mathrm{ppm}$ dan terendah pada konsentrasi 20 ppm. Ketika DPPH direaksikan dengan senyawa antioksidan maka DPPH akan tereduksi, dan terjadi perubahan warna larutan DPPH dari ungu menjadi kuning yang menandakan bahwa DPPH telah tereduksi. Hal tersebut sesuai dengan hasil penelitian yang diperoleh yaitu terjadi perubahan warna pada larutan DPPH dari DPPH berwarna ungu menjadi DPPH berwarna kuning.

Ekstrak etanol seledri (maserasi) terjadi perubahan warna dari ungu ke kuning pada konsentrasi 60 ppm, ekstrak air seledri (maserasi) terjadi perubahan warna dari ungu ke kuning pada konsentrasi 40 ppm, ekstrak air seledri (dekok) terjadi perubahan warna dari ungu ke kuning pada konsentrasi $80 \mathrm{ppm}$, dan vitamin $\mathrm{C}$ terjadi perubahan warna dari ungu ke kuning pada konsentrasi $20 \mathrm{ppm}$. Intensitas warna ungu pada DPPH semakin menurun seiring dengan bertambahnya konsentrasi ekstrak seledri sehingga nilai absorbansi juga semakin menurun, pengurangan intensitas warna yang terjadi berhubungan dengan jumlah elektron DPPH yang menangkap atom hidrogen dari senyawa antioksidan. Perubahan warna ini menandakan bahwa ekstrak seledri memiliki kemampuan sebagai antioksidan.

Adanya aktivitas antioksidan pada ekstrak seledri dikarenakan pada sampel mengandung senyawa aktif seperti flavonoid, tanin, steroid, dan saponin yang menjadi sumber antioksidan. Kandungan senyawa flavonoid pada ekstrak seledri menyebabkan ekstrak tersebut mempunyai aktivitas antioksidan, hal tersebut dikarenakan senyawa flavonoid merupakan senyawa golongan polifenol yang memiliki banyak gugus hidroksil $(\mathrm{OH})$. Atom hidrogen dari gugus hidroksil tersebut dapat didonorkan pada senyawa radikal sehingga senyawa tersebut dapat terstabilkan. Salah satu kelompok senyawa flavonoid adalah kuersetin yang memiliki lima gugus hidroksi yang mampu meredam radikal bebas DPPH.
Aktivitas antioksidan juga ditunjukkan oleh larutan pembanding yang digunakan yaitu vitamin C. Vitamin C merupakan salah satu zat antioksidan alami yang mempunyai berat molekul 178 gram $/ \mathrm{mol}$ dengan rumus molekul $\mathrm{C}_{6} \mathrm{H}_{8} \mathrm{O}_{6}$, vitamin $\mathrm{C}$ digunakan sebagai kontrol positif karena vitamin $\mathrm{C}$ merupakan antioksidan sekunder dan memiliki aktivitas antiksidan yang sangat kuat karena bersifat sebagai reduktor. Sifat reduktor tersebut disebabkan oleh mudah terlepasnya atom-atom hidrogen pada gugus hidroksi yang terikat pada atom $\mathrm{C}_{2}$ dan atom $\mathrm{C}_{3}$ (atom-atom $\mathrm{C}$ pada ikatan rangkap) sehingga radikal bebas dapat dengan mudah menangkapnya dan membentuk radikal bebas tereduksi yang stabil (Soewoto, 2001).

Perbandingan aktivitas antioksidan ekstrak seledri dan vitamin $\mathrm{C}$ dapat dilihat dari persen penghambat radikal dari beberapa sampel tersebut. Perbandingan persentase penangkap radikal bebas ekstrak seledri dan vitamin $\mathrm{C}$ dapat dilihat pada Gambar 4. Berdasarkan hasil pengamatan, menunjukkan bahwa beberapa ekstrak sampel memiliki persen penghambat yang sangat jauh berbeda dengan vitamin $\mathrm{C}$ dan ada juga ekstrak sampel yang memiliki persen penghambat yang tidak terlalu berbeda dengan vitamin C. Ini jelas terlihat pada ekstrak etanol seledri (maserasi) dan ekstrak air seledri (dekok) jika dibandingkan dengan vitamin $\mathrm{C}$, persen penghambatnya sangatlah berbeda jauh sedangkan pada ekstrak air seledri (maserasi) jika dibandingkan dengan dengan vitamin $\mathrm{C}$, persen penghambatnya tidaklah berbeda jauh, ini terlihat pada konsentrasi $40 \mathrm{ppm}$ persen penghambatnya lebih besar dibandingkan dengan vitamin $\mathrm{C}$.

Berdasarkan hal ini, maka dapat dikatakan untuk ekstrak etanol seledri (maserasi) dan ekstrak air seledri (dekok) memiliki aktivitas atioksidan yang hampir sama sedangkan untuk ekstrak air seledri (maserasi) dan vitamin C memiliki aktivitas antioksidan yang hampir sama, sehingga seledri dapat dijadikan sebagai zat antioksidan alami.

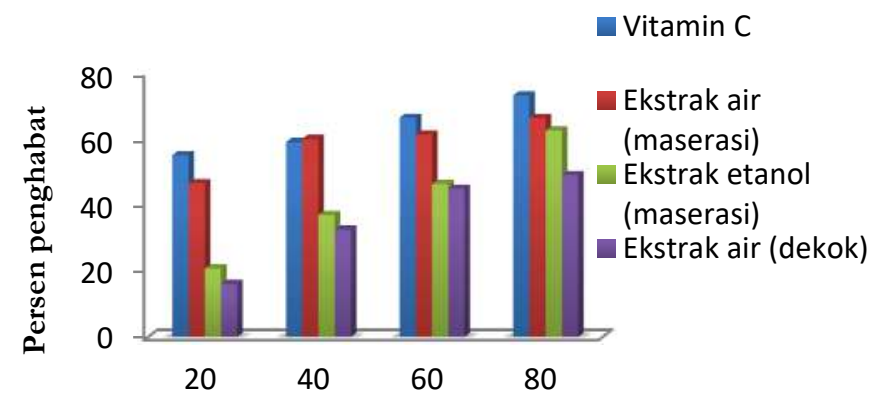

Konsentrasi ekstrak seledri dan vitamin C (ppm)

Gambar 4. Perbandingan persen penghambat ekstrak seledri dan vitamin C 


\section{Perhitungan Nilai IC $C_{50}$}

Kuat atau tidaknya aktivitas antioksidan dapat dilihat dari nilai $\mathrm{IC}_{50}$. $\mathrm{IC}_{50}$ adalah bilangan yang menunjukkan konsentrasi ekstrak yang mampu menghambat 50\% oksidasi. Semakin kecil nilai $\mathrm{IC}_{50}$, maka aktivitas antioksidan akan semakin tinggi (Larasati, 2017).

Nilai $\mathrm{IC}_{50}$ suatu ekstrak berada dibawah 50 ppm, maka aktivitas antioksidannya sangat kuat, nilai $\mathrm{IC}_{50}$ berada diantara $50-100 \mathrm{ppm}$, aktivitas antioksidannya kuat, nilai $\mathrm{IC}_{50}$ berada diantara 100-150 ppm, aktivitas antioksidannya sedang, nilai $\mathrm{IC}_{50}$ berada diantara $150-200 \mathrm{ppm}$, aktivitas antioksidannya lemah, dan nilai $\mathrm{IC}_{50}$ diatas 200 ppm, aktivitas antioksidannya sangat lemah (Molyneux, 2004). Hubungan antara probit dan log konsentrasi untuk ekstrak sampel dan vitamin

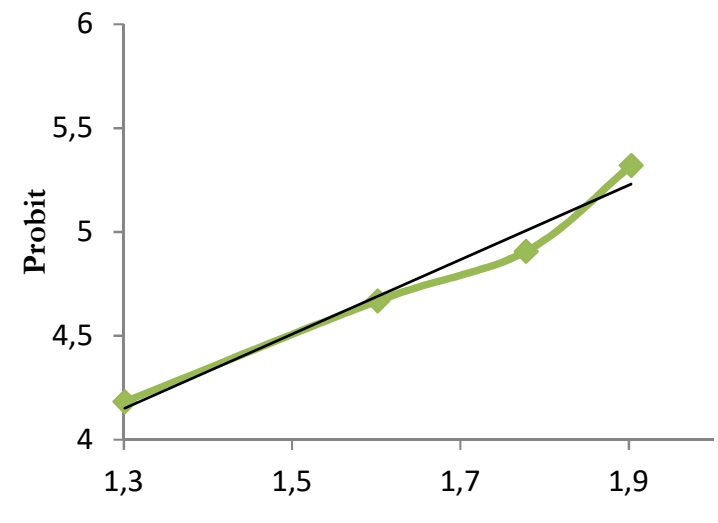

Log konsentrasi ekstrak seledri

(a)
C disajikan pada Gambar 5a-5b dan Gambar 6a$6 \mathrm{~b}$.

Gambar 5a menjelaskan hubungan antara probit dan log konsentrasi, memberikan nilai persamaan regresi linear yang membentuk garis lurus, $\mathrm{y}=1.7935 \mathrm{x}+1.8179$ dengan nilai $\mathrm{r}=0.9711$ sehingga diperoleh nilai $\mathrm{IC}_{50}$ sebesar $59.429 \mathrm{ppm}$ dan termasuk ke dalam senyawa yang memiliki aktivitas antioksidan kuat dan Gambar 5b menjelaskan hubungan antara probit dan log konsentrasi, memberikan nilai persamaan regresi linear yang membentuk garis lurus, $y=0.8108 \mathrm{x}+$ 3.8844 dengan nilai $r=0.9527$ sehingga diperoleh nilai $\mathrm{IC}_{50}$ sebesar $23.713 \mathrm{ppm}$ dan termasuk ke dalam senyawa yang memiliki aktivitas antioksidan sangat kuat.

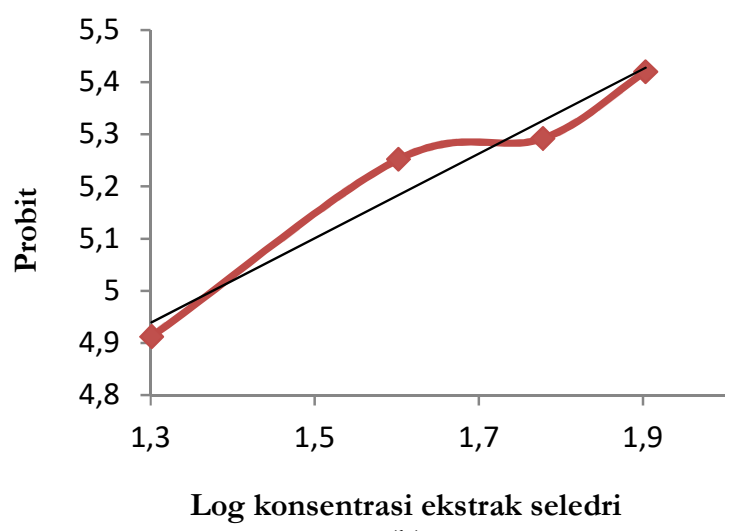

(b)

Gambar 5. Hubungan probit dan log konsentrasi (a) ekstrak etanol seledri; (b) ekstrak air seledri (maserasi)

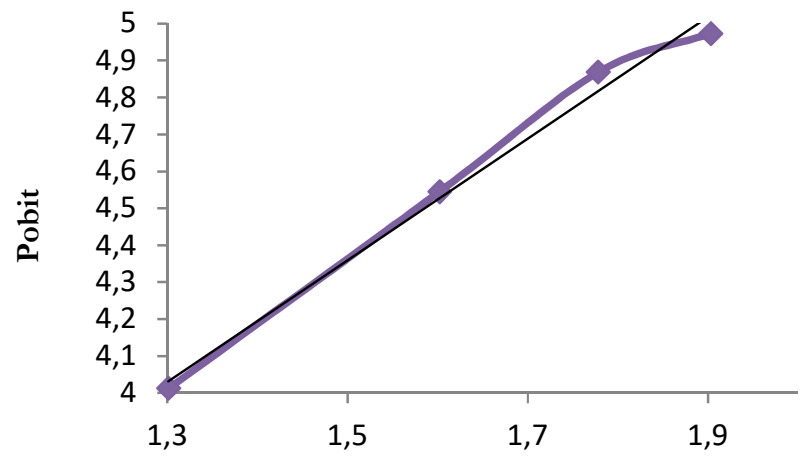

Log konsentrasi ekstrak seledri (a)

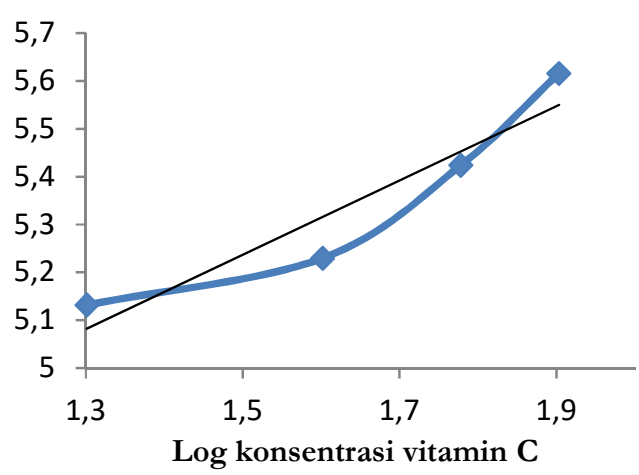

(b)

Gambar 6. Hubungan probit dan log konsentrasi (a) ekstrak air seledri (dekok); (b) Vitamin C 
Gambar 6a menjelaskan hubungan antara probit dan log konsentrasi, memberikan nilai persamaan regresi linear yang membentuk garis lurus, $\mathrm{y}=1.6461 \mathrm{x}+1.89$ dengan nilai $\mathrm{r}=0.9897$ sehingga diperoleh nilai $\mathrm{IC}_{50}$ sebesar 77.446 ppm dan termasuk ke dalam senyawa yang memiliki aktivitas antioksidan kuat dan Gambar 8 menjelaskan hubungan antara probit dan log konsentrasi, memberikan nilai persamaan regresi linear yang membentuk garis lurus, $y=0.7759 x+$ 4.0734 dengan nilai $\mathrm{r}=0.8908$ sehingga diperoleh nilai $\mathrm{IC}_{50}$ sebesar $15.631 \mathrm{ppm}$ dan termasuk ke dalam senyawa yang memiliki aktivitas antioksidan sangat kuat.

Dilihat dari hasil nilai $\mathrm{IC}_{50}$ bahwa ekstrak seledri memiliki aktivitas antioksidan yang berbeda, ekstrak air seledri (maserasi) memiliki aktivitas antioksidan yang sangat kuat jika dibandingkan dengan ekstrak etanol seledri (maserasi) dan ekstrak air seledri (dekok) yang memiliki aktivitas antioksidan kuat. Hal ini terjadi karena jenis pelarut dan metode ekstraksi yang digunakan mempengaruhi aktivitas antioksidan yang diperoleh, sehingga aktivitas antioksidan dari sampel seledri berbeda. Adanya perbedaan aktivitas antioksidan disebabkan kandungan flavonoid yang berbeda-beda pada proses ekstraksi seledri. Semakin tinggi total flavonoid, maka kadar aktivitas antioksidan juga meningkat, karena senyawa flavonoid dalam seledri bersifat sebagai antioksidan. Hal ini sesuai dengan penelitian Kusnadi \& Devi, (2017) bahwa seledri mengandung senyawa flavonoid.

Hasil ekstrak air seledri (maserasi) mempunyai aktivitas antioksidan yang sangat kuat dibandingkan ekstrak etanol seledri (maserasi) dan ekstrak air seledri (dekok), pada metode dekok kandungan flavonoid yang terkandung pada sampel sudah rusak karena mengalami pemanasan, senyawa flavonoid mudah teroksidasi pada suhu tinggi dan rusak pada suhu diatas $50^{\circ} \mathrm{C}$. Sehingga dapat dikatakan bahwa seledri dapat digunakan sebagai antioksidan alami, karena memiliki aktivitas antioksidan yang sangat kuat setara dengan vitamin $\mathrm{C}$.

\section{Kesimpulan}

Ekstrak air seledri (maserasi) memiliki daya antioksidan yang sangat kuat dengan nilai $\mathrm{IC}_{50}$ sebesar 23.713 ppm, ekstrak etanol seledri (maserasi) memiliki daya antioksidan yang kuat dengan nilai $\mathrm{IC}_{50}$ sebesar 59.429 ppm, ekstrak air seledri (dekok) memiliki daya antioksidan yang kuat dengan nilai $\mathrm{IC}_{50}$ sebesar 77.446 ppm, dan vitamin $\mathrm{C}$ memiliki daya antioksidan yang sangat kuat dengan nilai $\mathrm{IC}_{50}$ sebesar 15.631 ppm. Berdasarkan nilai $\mathrm{IC}_{50}$ yang diperoleh, ekstrak air seledri metode maserasi sangatlah baik untuk dijadikan sebagai salah satu sumber antioksidan alami, karena memiliki nilai aktivitas antioksidan yang sangat kuat yang setara dengan vitamin C.

\section{Ucapan Terima Kasih}

Ucapan terima kasih penulis berikan kepada laboran laboratorium Pendidikan Kimia Fakultas Keguruan dan Ilmu Pendidikan Universitas Tadulako dan semua pihak yang banyak membantu penulis dalam menyelesaikan penelitian ini.

\section{Referensi}

Bahriul, P., Rahman, N., \& Diah, A. W. M. (2014). Uji aktivitas antioksidan ekstrak daun salam (syzygium polyanthum) dengan menggunakan 1,1-Difenil-2-Pikrilhidrazil. Jurnal Akademika Kimia, 3(3), 143-149.

Bardan, S. N. (2007). Tumbuhan berkhasiat obat. Jakarta Selatan: PT. Sunda Kelapa Pustaka.

Harborn, J. B. (1987). Metode fitokimia penentuan cara modern menganalisis tumbuhan. Bandung: ITB.

Hariani, A. (2006). Tumbuhan obat dan khasiatnya seri III. Jakarta: Swaday.

Hernani, Marwati, T., \& Winarti, C. (2007). Pemilihan pelarut pada pemurnian ekstrak lengkuas (alpinia galanga) secara ekstraksi. Jurnal Pascapanen, 4(1), 1-8.

Hernani, \& Raharjo, M. (2005). Tanaman berkhasiat antioksidan. Jakarta: Penebar Swadya.

Isninandar, Wahyuono, S., \& Setyowati, E. P. (2011). Isolasi dan identifikasi senyawa antioksidan daun kesemek (diospyros kaki thunb.) dengan metode DPPH (2,2-Difenil-1Pikrilhidrazil). Majalah Obat Tradisional, 16(3), 161-169.

Khopkar, S. M. (2014). Konsep dasar kimia analitik. Jakarta: UI-Press.

Koirewoa, Y. A., Fatimawali, \& Wiyono, W. (2012). Isolasi dan indentifikasi senyawa flavonoid dalam daun beluntas (pluchea indica 1.). Pharmacon Jurnal Ilmiah Farmasi, 1(1), 47-52.

Kusnadi, K., \& Devi, E. T. (2017). Isolasi dan identifikasi senyawa flavonoid pada ekstrak daun seledri (apium graveolens 1.) dengan metode refluks. Pancasakti Science Education Journal, 2(1), 56-67.

Larasati, N. (2017). Studi aktivitas antioksidan dan ekstrak fisiko kimia tauco yang beredar di kota Malang, Jawa Timur. Jurnal Pangan dan Agroindustri, 5(2), 85-95.

Lumempow, L., Suryanto, E., \& Paendong, J. (2012). Aktivitas anti UV-B ekstrak fenolik dari tongkol jagung (zea mays 1.). Jurnal MIPA Unsrat Online, 1(1), 1-4. 
Molyneux, P. (2004). The use of the stable free radical diphenylpicryl-hydrazyl (DPPH) for estimating antioxidant activity. Songklanakarin Journal of Science and Technology, 26(2), 211-219.

Rizkayanti, Diah, A. W. M., \& Jura, M. R. (2017). Uji aktivitas antioksidan ekstrak air dan ekstrak etanol daun kelor (moringa oleifera lam). Jurnal Akademika Kimia, 6(2), 125131.

Sharon, N., Anam, S., \& Yuliet. (2013). Formulasi krim antioksidan ektrak etanol bawang hutan (eleutherine palmifolia l.merr). Natural Science: Journal of Science and Technology, 2(3), 111-122.

Singh, R. P., Sharad, S., \& Kapur. S. (2004). Free radicals and oxidative stress in neurodegenerative diseases relevance of dietary antioxidants. Journal Indian Academy of Clinical Medicine, 5(3), 218-225.

Soewoto, H. (2001). Antioksidan eksogen lini pertahanan kedua dalam menanggulangi peran radikal bebas. Jakarta: FK-UI.

Sukahor, A., \& Arisandi, R. (2016). Seledri (apium graveolens 1.) sebagai agen kemopreventif bagi kanker. Medical Journal of Lampung University, 5(2), 95-96.

Sulaeha, S., Jura, M. R., \& Rahman, N. (2017). Uji aktivitas antioksidan ekstrak etanol biji buah merah (pandanus conoideus de vriese) asal Kabupaten Poso Sulawesi Tengah. Jurnal Akademika Kimia, 6(3), 170-174.

Talapessy, S., Suryanto, E., \& Yudistira, A. (2013). Uji aktivitas antioksidan dari ampas hasil pengolahan sagu (metroxylon sagu rottb). Pharmacon Jurnal Ilmiah Farmasi, 2(3), 112-117.

Wahdaningsih, S., Setyowati, E. P., \& Wahyuono, S. (2011). Aktivitas penangkap radikal bebas dari batang pakis (alsophila glauca j. sm). Majalah Obat Tradisional, 16(3), 156-160.

Zuhra, C. F., Tarigan, J. B., \& Sihotang, H. (2008). Aktivitas antioksidan senyawa flavonoid dari daun Katuk (sauropus androgunus(1) merr.). Jurnal Biologi Sumatera, 3(1), 7-10.

Zuhrotun, A., Hidayati, A. S., Mustarichie, R., \& Indrayati, W. (2015). Aktivitas antioksidan ekstrak dan fraksi tauco dengan metode DPPH. Jurnal Kesehatan, 1(1), 209-214. 